\title{
Effect of shearing on some physiological and hormonal parameters in Akkaraman sheep
}

\author{
Erkan Pehlivan ${ }^{1, *}$, Mahmut Kaliber ${ }^{2}$, Yusuf Konca ${ }^{2}$, and Gürsel Dellal'
}

* Corresponding Author: Erkan Pehlivan Tel: +90-312-5961374, Fax: +90-312-5170533,

E-mail: pehlivan@agri.ankara.edu.tr

'Department of Animal Science, Faculty of Agriculture, Ankara University, Ankara 06110, Turkey

${ }^{2}$ Department of Animal Science, Faculty of Agriculture, Erciyes University, Kayseri 38039, Turkey

ORCID

Erkan Pehlivan

https://orcid.org/0000-0003-2505-1456

Mahmut Kaliber

https://orcid.org/0000-0001-5572-6384

Yusuf Konca

https://orcid.org/0000-0002-6231-1512

Gürsel Dellal

https://orcid.org/0000-0002-8129-982X

Submitted May 15, 2019; Revised Jul 26, 2019; Accepted Sept 2, 2019
Objective: Shearing is one of the practices that is applied periodically to fiber producing animals, which can also alter resistance of animals to high temperatures in especially summer months. This study aimed to investigate effects of shearing on some physiological and hormonal parameters in Akkaraman sheep during summer season.

Methods: This study was carried out on 39 non-pregnant Akkaraman ewes (aged 1.5 years at the beginning of experiment). The 39 ewes were chosen randomly from the flock belonging to the Erciyes University and they were assigned to two groups as follows: i) group A ( $n=20)$ designed as the control group, they were shorn and group $\mathrm{B}(\mathrm{n}=19)$ designed as the experimental group, they were unshorn. Prior to the shearing (-1 day) and on days $1,7,15,30$, $45,60,75$, and 90 following the shearing, blood samples were taken from the vena jugularis of each sheep. Cortisol, $\beta$-endorphin, growth hormone $(\mathrm{GH})$, thyroxine $\left(\mathrm{T}_{4}\right)$, triiodothyronine $\left(\mathrm{T}_{3}\right)$, and heat shock protein 70 (HSP-70) concentrations were determined using the enzyme immunoassay method. Body weight (BW), rectal temperature (RT), pulse rate (PR), and respiratory rate (RR) of each sheep were recorded at the same time. The data obtained were analyzed using two-way repeated measures analysis of variance.

Results: Statistical analysis showed a significant effect of shearing $\times$ period interaction $(\mathrm{p}<$ 0.01 ) and a significant effect of period ( $\mathrm{p}<0.01)$ on BW, HSP-70, cortisol, $\mathrm{T}_{4}$ and RT, PR, GH, $\beta$-endorphin, $\mathrm{T}_{3}$, respectively. Also these analysis showed no significant effect of shearing $x$ period interaction or period on RR.

Conclusion: The results showed that the thermoregulation abilities of sheep were affected by shearing treatment and the shorn ewes were less affected by heat stress. In conclusion, based on the data of this study, shearing can be considered as a necessary management practice that requires protection for sheep from the effect of heat stress.

Keywords: Stress; Fleece; Thermoregulation; Climatic Factors; Homeostasis

\section{INTRODUCTION}

There are many different practices such as tagging, tail docking, dehorning, castration, weaning, vaccination, bathing, hoof trimming and shearing in sheep husbandry. Some of these practices are performed only once in the animal's lifespan, while others are necessarily repeated periodically and these may cause an endocrine and metabolic response to occur in animals known as stress [1,2]. Animals that are exposed to stress react in speciesspecific behavioral patterns that are also influenced by learned behavior, and there are differences between animals in response to these behaviors. Animals, depending on their genetic structure and previous experience, can respond differently to the same stressors. Moreover age, gender, physiological status, herd density, daily rhythm and other environmental factors can also affect the individual reactions that animals show against the stressors $[3,4]$. Under different environment and management conditions, animals that are exposed 
to stressors continue their existence and production through behavioral responses, metabolic changes that occur in different biological systems, along with physiological parameters such as heart rate, respiration rate and as well as body temperature. During the stress, maintenance of the homeostasis of the animal is carried out essentially through the control of the physiological processes, mainly cortisol and other stress hormones as well as metabolic hormones such as thyroxine $\left(\mathrm{T}_{4}\right)$, triiodothyronine $\left(\mathrm{T}_{3}\right)$, insulin-like growth factor-1, growth hormone $(\mathrm{GH})$, and $\beta$-endorphin which also play role in these control processes $[4,5]$. By monitoring, measuring and evaluating the changes in these biological parameters, it is possible to decide on the type, stage and precautions to take against stress $[3,4,6]$.

Occasionally, different stress factors can also be effective in sheep breeding. While some of these stress factors are mainly due to inadequate and/or poor feed and water resources, climatic factors such as high temperature and humidity may also be effective especially in some periods. Fleece plays an important role in the response of sheep to these climatic factors. The fleece has a natural thermoregulatory structure and it provides thermal insulation which reduces convective heat loss from the body under cold environment conditions and radiative heat gain from the environment under hot environment conditions $[7,8]$. In addition, fleece is an economic product which has a significant share among the breeders' incomes. Therefore, although it varies according to the countries, the shearing is usually done once a year to harvest the wool of sheep [9]. As in many European countries [9], traditionally shearing time in Turkey is the spring and early summer seasons that coincide with temperate climates. The shearing is considered not only for hygienic reasons but also as a compulsory practice to improve the sheep's' resistance to high temperatures in summer [10]. During shearing, animals' welfare is adversely affected, and short-term acute stress occurs [11-13]. The acute stress that occurs during the shearing is not only due to the shearing, but also from the preparation procedures such as capture, separation, immobilization and tying required for the shearing. However, this traditional practice also means harvesting the fleece which provides protection against the external factors. In some of the studies performed in this field, it was reported that shearing increased the sensitivity of the animals to thermal stress [8,10-15], in others $[2,16,17]$, that the removal of fleece did not have a significant effect on the physiology of the sheep or that sheep were becoming more resistant to thermal stress after shearing. However, fleece properties of sheep have a very important role in the response of sheep to thermal stress [18].

From this point of view, this study was aimed to determine both effect of shearing and the reactions against climatic factors after shearing on some physiological and hormonal parameters in young Akkaraman ewes that not previously been sheared.

\section{MATERIALS AND METHODS}

\author{
Animal care \\ The experimental procedure was approved by Local Ethics \\ Committee at Erciyes University (16/004).
}

Location, experimental animals, shearing procedures, and experimental groups

This study was carried out between June and September months of 2016 in a farm entitled Erciyes University Agricultural Research and Application Centre (ERUTAM) located in Kayseri, Turkey $\left(38^{\circ} 29^{\prime} 21.5^{\prime \prime} \mathrm{N} ; 35^{\circ} 10^{\prime} 11.7^{\prime \prime}\right.$ E) at an altitude of approximately 1,130 meters above sea level. The study was conducted on 1,5 years old 39 non-pregnant Akkaraman ewes at the beginning of the experiment. The 39 ewes were chosen randomly from the flock belonging to the Erciyes University. During 15 days prior to starting of the study, all ewes were identified and subjected to internal and external parasite controls. The following experimental protocol was used: the ewes were randomly divided into two groups; i) Group A ( $n=20)$ designed as the control group, and were shorn and group $B(n=19)$ designed as the experimental group, and were unshorn. The shearing was performed via sheep shearing machine (Xpert 708-200, Heiniger AG, Herzogenbuchsee, Switzerland) 11:00 am and 2:00 pm on the same day, without any interruption. All the ewes were clinically healthy. During the experimental period, the ewes grazed on natural pasture between 7:00-10:00 am and between 4:0007:00 pm and they were housed in shaded pens $\left(2 \mathrm{~m}^{2}\right.$ per sheep) in the remaining time and natural light from windows and a door could pass through to the pens. The ewes were fed with $400 \mathrm{~g}$ concentrated commercial feed and $400 \mathrm{~g}$ alfalfa hay per head as a supplement in every day during this period and they were not milking. Fresh water was always available to the ewes. The study was conducted within standard ethical norms.

\section{Blood collection and determination of body weight and some physiological parameters}

Blood samples $(8 \mathrm{~mL})$ were taken regularly from the vena jugularis of each ewe into vacuum containers without any anticoagulant (VACUETTE TUBE $8 \mathrm{~mL}$ Z Serum Sep Clot Activator, Greiner Bio-One, Kremsmünster, Austria) on experimental days before shearing ( -1 day) and after shearing ( 1 day) and were repeated after $7,15,30,45,60,75$, and 90 days from the shearing date. The blood samples randomly taken from the 8 ewes in each group (group $A, n=8$, group $\mathrm{B}, \mathrm{n}=8)$ within 1 hour $(1: 00 \mathrm{pm}$ and 2:00 $\mathrm{pm})$ were subjected to hormone analysis. Samples were centrifuged at 3,000 rpm for $10 \mathrm{~min}$ and the serum was separated and stored at $-20^{\circ} \mathrm{C}$ 
until analysis time. Body weight (BW), pulse rate (PR), respiratory rate (RR), and rectal temperatures (RT) of each ewe were determined on the same times (2:00 pm and 4:00 pm) of same days as the blood collection days. The BW were determined using a digital scale $( \pm 100 \mathrm{~g}$, Beko, TEM Terazi, İstanbul, Turkey). The RR and PR were measured using a stethoscope (Classic III, 3M Littmann, St. Paul, MN, USA). The RT was measured with a digital thermometer (FTC-77030, Medisana, Neuss, Germany) with the probe being inserted into the ewes' rectum to a depth of $4 \mathrm{~cm}$.

\section{Hormone analysis}

Analysis of hormones in the blood serum were performed by enzyme immunoassay method using microplate washer (W206, EMP Medical, Shenzhen, Guangdong, China) and microplate reader (M201, EMP Medical, China) in the Laboratory of Animal Physiology and Endocrinology at Erciyes University, Faculty of Agriculture, Department of Animal Science. The GH (Sunred, 201-07-0075, Shanghai, China), heat shock protein 70 (HSP-70; Sunred, 201-07-1139, China), $\beta$-endorphin (Sunred, 201-07-0095, China), cortisol (Sunred, 201-07-0067, China), $\mathrm{T}_{3}$ (Sunred, 201-07-1022, China), and $\mathrm{T}_{4}$ (Sunred, 201-07-1026, China) concentrations were determined using species-specific commercial enzyme linked immunosorbent assay kits. The minimum detectable concentrations of the kits were $0.066 \mathrm{ng} / \mathrm{mL}, 0.46 \mathrm{ng} / \mathrm{mL}, 4.827$ $\mathrm{ng} / \mathrm{L}, 0.183 \mathrm{ng} / \mathrm{mL}, 0.242 \mathrm{nmol} / \mathrm{L}$, and $9.005 \mathrm{nmol} / \mathrm{L}$ for $\mathrm{GH}$, HSP-70, $\beta$-endorphin, cortisol, $\mathrm{T}_{3}$, and $\mathrm{T}_{4}$, respectively.

\section{Climatic values}

Climatic values on the location of the farm where the experiment was carried out, were obtained from Turkish State Meteorological Service [19] in order to estimate the severity of heat stress during the experimental period. Temperaturehumidity index (THI) were calculated using the equation below reported by Marai et al [20] for sheep and goats [21].

$$
\mathrm{THI}=\mathrm{db}^{\circ} \mathrm{C}-\left[(0.31-0.31 \mathrm{RH} / 100)\left(\mathrm{db}{ }^{\circ} \mathrm{C}-14.4\right)\right]
$$

where $\mathrm{db}{ }^{\circ} \mathrm{C}$ is the dry bulb temperature $\left({ }^{\circ} \mathrm{C}\right)$ and $\mathrm{RH}$ is the relative humidity $(\mathrm{RH} \%) / 100$. The values obtained indicate the following: $<22.2$, absence of heat stress; 22.2 to $<23.3$, moderate heat stress; 23.3 to $<25.6$, severe heat stress; and 25.6 and more, extreme severe heat stress [21].

\section{Statistical analysis}

The data obtained from the experiment were analyzed using two-way repeated measures analysis of variance (ANOVA). Sources of variation were group (A and B), period $(-1,+1,+7$, $+15,+30,+45,+60,+75,+90)$ and their interactions. Duncan multiple comparison test was performed to determine significant differences between groups and periods. The IBM
SPSS STATISTICS 20 software package was used to perform ANOVA and MSTAT-C statistical software was used to Duncan multiple comparison tests [22].

\section{RESULTS}

The values of average environmental temperature, relative humidity levels and THI on the sampling days are presented in Table 1. As can be seen from Table 1, values of average temperature and THI increased substantially in the second half of the experiment and the ewes were affected by severe heat stress on the 45th and 60th days of the experiment and moderate heat stress on the 90th day.

The average values of BW, RT, PR, RR, and GH, HSP-70, $\beta$-endorphin, cortisol, $\mathrm{T}_{3}$, and $\mathrm{T}_{4}$ in the groups during the experiment are presented in Table 2 and 3, respectively. Statistical analysis showed a significant effect of shearing $\times$ period interaction $(\mathrm{p}<0.01)$ and a significant effect of period $(\mathrm{p}<0.01)$ on BW, HSP-70, cortisol, $\mathrm{T}_{4}$, and RT, PR, GH, $\beta$-endorphin, $\mathrm{T}_{3}$, respectively. Also, these analysis showed no significant effect of shearing $\times$ period interaction or period on RR.

\section{DISCUSSION}

Carcangiu et al [1] reported that not only the shearing, but also the preparation procedures caused acute stress in sheep. In this study, no significant difference was found on the obtained values (except BW and T4) between before shearing and 1 day after shearing (Tables 1,2). This may be due to the first sampling being on 1st day after shearing. So indeed, acute stress is a process that develops very rapidly and disappears a short time after the stressor disappears [6]. It has been reported in the studies conducted on this field that cortisol hormone started to decrease towards basal level with the disappearance of acute stressors in ewes [23-25]. As a result, shearing (including preparation procedures for shearing) causes acute stress but the ewes rapidly regain their body homeostasis

Table 1. Average temperature $\left({ }^{\circ} \mathrm{C}\right)$, relative humidity $(\%)$, and $\mathrm{TH}$ during the experimental days

\begin{tabular}{lccc}
\hline Days & $\begin{array}{c}\text { Average } \\
\text { temperature }\left({ }^{\circ} \mathrm{C}\right)\end{array}$ & $\begin{array}{c}\text { Relative } \\
\text { humidity }(\%)\end{array}$ & THI \\
\hline Before shearing & 18.8 & 68.3 & 18.4 \\
After shearing $(+1)$ & 17.1 & 73.3 & 16.9 \\
After 7 days $(+7)$ & 20.3 & 59.5 & 19.6 \\
After 15 days $(+15)$ & 18.5 & 61.9 & 18.0 \\
After 30 days $(+30)$ & 23.3 & 51 & 21.9 \\
After 45 days $(+45)$ & 26.1 & 28.8 & 23.5 \\
After 60 days $(+60)$ & 26.6 & 40 & 24.3 \\
After 75 days $(+75)$ & 20.2 & 47 & 19.2 \\
After 90 days $(+90)$ & 24.7 & 43.3 & 22.9 \\
\hline
\end{tabular}

$\mathrm{TH}$, temperature-humidity index. 
Table 2. Average values ( \pm standard error) of body weight, rectal temperature, pulse rate, and respiratory rate in the groups during the experiment

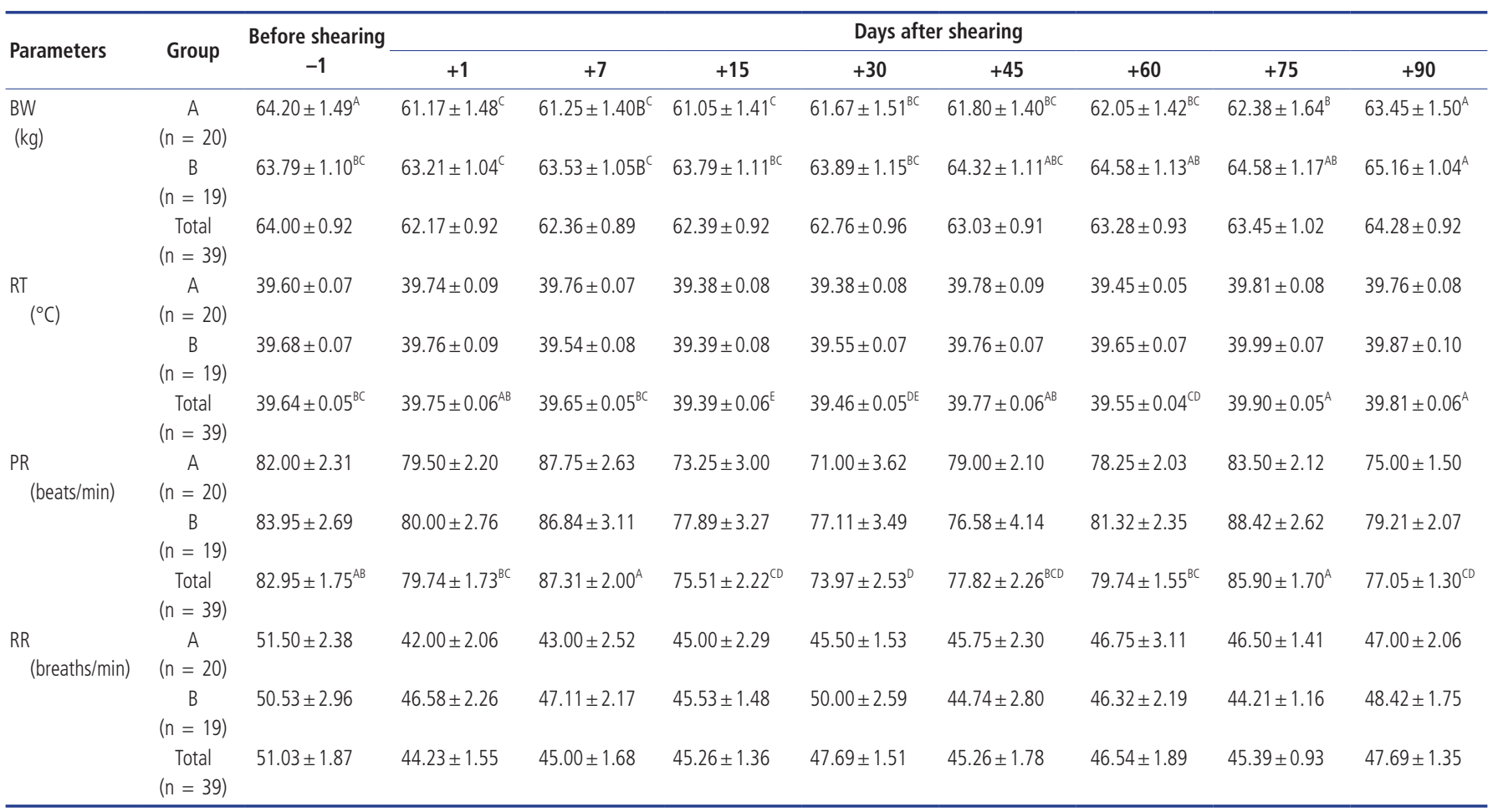

BW, body weight; RT, rectal temperature; $P R$, pulse rate; RR, respiratory rate.

A-C Mean values within a row with different capital letters differ significantly $(p<0.01)$ in sample comparison.

with the disappearance of these stressors.

Although shearing is a management practice causing acute stress, it can also alter the thermal homeostasis of the ewes. Because, thermal regulation in ewes is mainly influenced by their fleece properties among other factors [18]. In addition, climatic factors also play an important role in thermal homeostasis of sheep together with endogenous factors such as breed, age, gender and physiological status $[10,15,16]$. Climatic factors include thermal irradiation and wind speed as well as THI are evaluated together to determine the intensity of heat stress [15,21]. In the present study, THI values reached levels that will generate heat stress conditions after the 30th day of the experimental period. The ewes were affected by severe heat stress on the 45th and 60th days of experiment and moderate heat stress on the 90th day (Table 1).

The RT, PR, and RR as physiological responses are considered as indicators of the degree of thermal stress [26]. In this study, no significant difference was found between the groups in terms of these physiological parameters. However, the effect of period on RT and PR was significant $(\mathrm{p}<0.01)$ (Table 2) and the RT and PR of sheep reached higher levels in periods of heat stress than other periods (Figure 1). In fact, when animals are exposed to thermal stress, RT, RR, and PR are increased [27]. However, in this study, the RT and PR of the shorn ewes (group A) were generally lower than the unshorn ewes (group B). It can be said that this is due to the better adjustment of the heat distribution of the shorn animals, because fleece is an important factor affecting heat distribution in the body [9]. Fleece inhibits evaporation of water from the body reducing heat loss through sweating [28]. For this reason, the removal of fleece facilitates the adaptation of the ewes to high temperatures. It has been reported that at high ambient temperatures, shorn ewes dispersed 50\% of body heat by means of evaporation better than unshorn ewes [29]. These findings were consistent with the findings obtained from previous studies $[14,16,17,30,31]$ conducted in different sheep breeds.

Hormonal signal system plays a vital role in regulating homeostasis in organisms [4]. The main hormones in coping with stress are glucocorticoids and catecholamines. Changes in the concentrations of these hormones are indicative of adrenal activity [32]. In this study, the cortisol concentrations increased in parallel with the increase in environmental temperature in the unshorn ewes (group B) and reached the highest levels after with the onset of heat stress. The release of cortisol during stress varies according to the type and intensity of stress [4]. Thus, cortisol contributes to the preservation of homeostasis by regulating energy metabolism during stress. Adverse environmental conditions cause an increase in the secretion of the cortisol hormone in organism [33]. On the other hand, there was a significant decrease $(\mathrm{p}<0.01)$ of cortisol concentrations in the shorn ewes during 
Table 3. Average values ( \pm standard error) of cortisol, $\beta$-endorphin, growth hormone, $T_{4}, T_{3}$, and HSP-70 in the groups during the experiment

\begin{tabular}{|c|c|c|c|c|c|c|c|c|c|c|}
\hline \multirow{2}{*}{ Parameters } & \multirow{2}{*}{ Group } & \multirow{2}{*}{$\begin{array}{c}\text { Before shearing } \\
-1\end{array}$} & \multicolumn{8}{|c|}{ Days after shearing } \\
\hline & & & +1 & +7 & +15 & +30 & +45 & +60 & +75 & +90 \\
\hline \multirow[t]{3}{*}{$\begin{array}{l}\text { Cortisol } \\
\text { (ng/mL) }\end{array}$} & $\begin{array}{c}A \\
(n=8)\end{array}$ & $26.57 \pm 6.54^{A}$ & $26.23 \pm 7.04^{A}$ & $25.88 \pm 6.84^{A}$ & $26.01 \pm 6.67^{A}$ & $26.05 \pm 7.10^{A}$ & $19.86 \pm 4.56^{B}$ & $19.13 \pm 4.28^{\mathrm{Bb}}$ & $19.23 \pm 4.46^{\mathrm{Bb}}$ & $18.93 \pm 4.38^{\mathrm{Bb}}$ \\
\hline & $\begin{array}{c}B \\
(n=8)\end{array}$ & $27.04 \pm 4.87^{\AA}$ & $26.96 \pm 4.83^{A}$ & $27.73 \pm 4.43^{\mathrm{A}}$ & $27.82 \pm 4.35^{A}$ & $27.77 \pm 4.42^{A}$ & $28.69 \pm 4.52^{A}$ & $28.90 \pm 4.42^{\mathrm{Aa}}$ & $29.32 \pm 3.98^{\mathrm{Aa}}$ & $29.52 \pm 3.78^{\mathrm{Aa}}$ \\
\hline & $\begin{array}{c}\text { Total } \\
(n=16)\end{array}$ & $26.80 \pm 3.94$ & $26.59 \pm 4.12$ & $26.80 \pm 3.94$ & $26.92 \pm 3.85$ & $26.91 \pm 4.05$ & $24.28 \pm 3.30$ & $24.01 \pm 3.23$ & $24.28 \pm 3.17$ & $24.23 \pm 3.11$ \\
\hline \multirow[t]{3}{*}{$\begin{array}{l}\beta \text {-Endorphin } \\
\quad \text { (ng/L) }\end{array}$} & $\begin{array}{c}A \\
(n=8)\end{array}$ & $758.00 \pm 218.00$ & $839.00 \pm 261.00$ & $1,286.00 \pm 320.00$ & $1,970.00 \pm 618.00$ & $1,719.00 \pm 515.00$ & $433.00 \pm 76.40$ & $397.40 \pm 76.20$ & $368.00 \pm 69.20$ & $366.00 \pm 62.40$ \\
\hline & $\begin{array}{c}B \\
(n=8)\end{array}$ & $695.50 \pm 40.40$ & $806.50 \pm 87.70$ & $1,231.00 \pm 209.00$ & $1,693.00 \pm 305.00$ & $1,159.00 \pm 155.00$ & $431.20 \pm 54.60$ & $382.30 \pm 45.70$ & $372.60 \pm 37.50$ & $349.20 \pm 42.90$ \\
\hline & $\begin{array}{c}\text { Total } \\
(n=16)\end{array}$ & $727.00 \pm 107.00^{C D}$ & $823.00 \pm 133.00^{c}$ & $1,259.00 \pm 185.00^{B}$ & $1,832.00 \pm 335.00^{A}$ & $1,439.00 \pm 270.00^{B}$ & $432.10 \pm 45.40^{D}$ & $389.90 \pm 43.00^{D}$ & $370.30 \pm 38.00^{D}$ & $357.60 \pm 36.60^{\circ}$ \\
\hline \multirow[t]{3}{*}{$\begin{array}{l}\mathrm{GH} \\
\qquad(\mathrm{ng} / \mathrm{mL})\end{array}$} & $\begin{array}{c}\text { A } \\
(n=8)\end{array}$ & $4.66 \pm 1.20$ & $4.96 \pm 1.23$ & $5.48 \pm 1.48$ & $6.50 \pm 1.42$ & $6.49 \pm 1.45$ & $6.21 \pm 1.33$ & $6.20 \pm 1.23$ & $6.16 \pm 1.17$ & $6.19 \pm 0.95$ \\
\hline & $\begin{array}{c}B \\
(n=8)\end{array}$ & $3.82 \pm 0.98$ & $4.01 \pm 0.97$ & $4.68 \pm 0.86$ & $5.86 \pm 0.84$ & $5.81 \pm 0.90$ & $5.27 \pm 0.83$ & $5.12 \pm 0.74$ & $4.84 \pm 0.79$ & $4.69 \pm 0.80$ \\
\hline & $\begin{array}{c}\text { Total } \\
(n=16)\end{array}$ & $4.24 \pm 0.76^{D}$ & $4.49 \pm 0.77^{C D}$ & $5.08 \pm 0.83 B^{C D}$ & $6.18 \pm 0.80^{A}$ & $6.15 \pm 0.83^{A}$ & $5.74 \pm 0.77^{A B}$ & $5.66 \pm 0.71^{A B}$ & $5.50 \pm 0.70^{A B}$ & $5.44 \pm 0.63^{\mathrm{ABC}}$ \\
\hline \multirow[t]{3}{*}{$\begin{array}{l}\mathrm{T}_{4} \\
\quad(\mathrm{nmol} / \mathrm{L})\end{array}$} & $\begin{array}{c}A \\
(n=8)\end{array}$ & $69.13 \pm 1.66^{C D}$ & $71.99 \pm 1.62^{A}$ & $71.69 \pm 1.60^{\mathrm{AB}}$ & $70.87 \pm 1.85^{\mathrm{AB}}$ & $70.42 \pm 1.54^{B C}$ & $69.38 \pm 1.74^{\mathrm{CD}}$ & $69.09 \pm 1.73^{\mathrm{CD}}$ & $69.18 \pm 2.06^{\mathrm{CD}}$ & $69.00 \pm 1.92^{D}$ \\
\hline & $\begin{array}{c}\text { B } \\
(n=8)\end{array}$ & $69.47 \pm 1.19^{A}$ & $69.35 \pm 1.30^{A B}$ & $69.39 \pm 1.46^{\mathrm{AB}}$ & $68.99 \pm 1.47^{A B}$ & $69.06 \pm 1.51^{\mathrm{AB}}$ & $69.33 \pm 1.35^{A B}$ & $69.01 \pm 1.34^{A B}$ & $68.71 \pm 1.36^{A B}$ & $68.04 \pm 1.32^{B}$ \\
\hline & $\begin{array}{c}\text { Total } \\
(n=16)\end{array}$ & $69.30 \pm 0.99$ & $70.67 \pm 1.06$ & $70.54 \pm 1.09$ & $69.93 \pm 1.17$ & $69.74 \pm 1.06$ & $69.36 \pm 1.07$ & $69.05 \pm 1.06$ & $68.94 \pm 1.20$ & $68.52 \pm 1.13$ \\
\hline \multirow[t]{3}{*}{$\begin{array}{l}\mathrm{T}_{3} \\
\quad(\mathrm{nmol} / \mathrm{L})\end{array}$} & $\begin{array}{c}A \\
(n=8)\end{array}$ & $34.32 \pm 7.47$ & $34.68 \pm 7.65$ & $34.74 \pm 7.14$ & $33.97 \pm 6.43$ & $33.43 \pm 6.64$ & $31.49 \pm 6.39$ & $30.69 \pm 5.42$ & $30.96 \pm 5.49$ & $30.54 \pm 5.43$ \\
\hline & $\begin{array}{c}B \\
(n=8)\end{array}$ & $34.43 \pm 6.46$ & $33.71 \pm 5.85$ & $32.89 \pm 5.45$ & $32.13 \pm 5.81$ & $30.85 \pm 6.57$ & $28.54 \pm 5.98$ & $28.39 \pm 6.04$ & $27.13 \pm 5.79$ & $26.49 \pm 6.05$ \\
\hline & $\begin{array}{c}\text { Total } \\
(n=16)\end{array}$ & $34.37 \pm 4.77^{\AA}$ & $34.19 \pm 4.65^{A B}$ & $33.81 \pm 4.35^{\mathrm{AB}}$ & $33.05 \pm 4.20^{A B}$ & $32.14 \pm 4.52^{B}$ & $30.01 \pm 4.24^{c}$ & $29.54 \pm 3.93^{C}$ & $29.05 \pm 3.89^{c}$ & $28.52 \pm 3.96^{C}$ \\
\hline \multirow[t]{3}{*}{$\begin{array}{l}\text { HSP-70 } \\
\qquad(\mathrm{ng} / \mathrm{mL})\end{array}$} & $\begin{array}{c}A \\
(n=8)\end{array}$ & $40.62 \pm 8.96^{\mathrm{E}}$ & $40.83 \pm 9.18^{\mathrm{E}}$ & $40.96 \pm 9.30^{\mathrm{E}}$ & $46.60 \pm 10.00^{E}$ & $53.20 \pm 10.90^{D}$ & $59.60 \pm 11.00^{c}$ & $67.60 \pm 10.30^{B}$ & $73.70 \pm 11.00^{A B}$ & $79.02 \pm 9.91^{A}$ \\
\hline & $\begin{array}{c}B \\
(n=8)\end{array}$ & $51.47 \pm 9.86^{\mathrm{D}}$ & $51.90 \pm 10.00^{C D}$ & $51.73 \pm 9.84^{C D}$ & $52.19 \pm 9.91^{C D}$ & $55.87 \pm 9.71^{B C D}$ & $58.71 \pm 9.96^{A B C}$ & $61.60 \pm 11.00^{A B}$ & $62.70 \pm 10.70^{A B}$ & $64.50 \pm 11.10^{A}$ \\
\hline & $\begin{array}{c}\text { Total } \\
(n=16)\end{array}$ & $46.05 \pm 6.58$ & $46.38 \pm 6.72$ & $46.35 \pm 6.69$ & $49.38 \pm 6.86$ & $54.56 \pm 7.05$ & $59.15 \pm 7.16$ & $64.60 \pm 7.32$ & $68.20 \pm 7.55$ & $71.77 \pm 7.42$ \\
\hline
\end{tabular}

GH, growth hormone; $T_{4}$, thyroxine; $T_{3}$, triiodothyronine; HSP-70, heat shock protein 70 .

A-E Mean values within a row with different capital letters differ significantly $(p<0.01)$ in sample comparison.

$a, b$ Mean values within a column with different lower-case symbol differ significantly $(p<0.01)$ in group comparison.

the same period in this study. Apparently, these ewes were not intensely affected by heat stress due to the removal of their fleece. Therefore, this was due to the lowering of cortisol levels in order to decrease metabolic rate due to increase of temperature. $\beta$-Endorphin is a compound that plays a role in stress response like cortisol [34]. In this study, $\beta$-endorphin concentrations were found to be high until the onset of the heat stress in both groups and then it decreased suddenly and reached its lowest concentrations during the periods of heat stress. Although we could not find other studies to compare these values obtained during heat stress in sheep, it may be that this decrease in $\beta$-endorphin concentrations was related to a negative feedback mechanism of cortisol. In addition to cortisol, metabolic hormones such as $\mathrm{GH}, \mathrm{T}_{4}$, and $\mathrm{T}_{3}$ are also affected by stress and therefore, it is reported that changes in the concentrations of these hormones may be an indicative assessment of animal welfare [4,5]. Although
$\mathrm{GH}$ is one of the hormones involved in stress response, changes in $\mathrm{GH}$ concentrations during stress vary between species [1]. In this study, GH concentrations were increased until the onset of the heat stress periods in both groups and then decreased $(p<0.01)$ during the heat stress periods and this decrease was more severe in the unshorn group (group B). As a matter of fact, $\mathrm{GH}$ concentrations decrease significantly depending on the type and severity of stress during longterm stress conditions $[4,35]$. Therefore, it can be said that this decrease in GH concentrations was caused by the decrease in the anabolic activities of organism due to the presence of stress. Similar results were also observed in bovines [36]. Todini [37] reported that systemic functions of thyroid hormones play a crucial role in the mechanisms enabling the adaptation of the animals to the environment and these hormones levels in circulation may decrease depending on high temperature and increase depending on low tempera- 

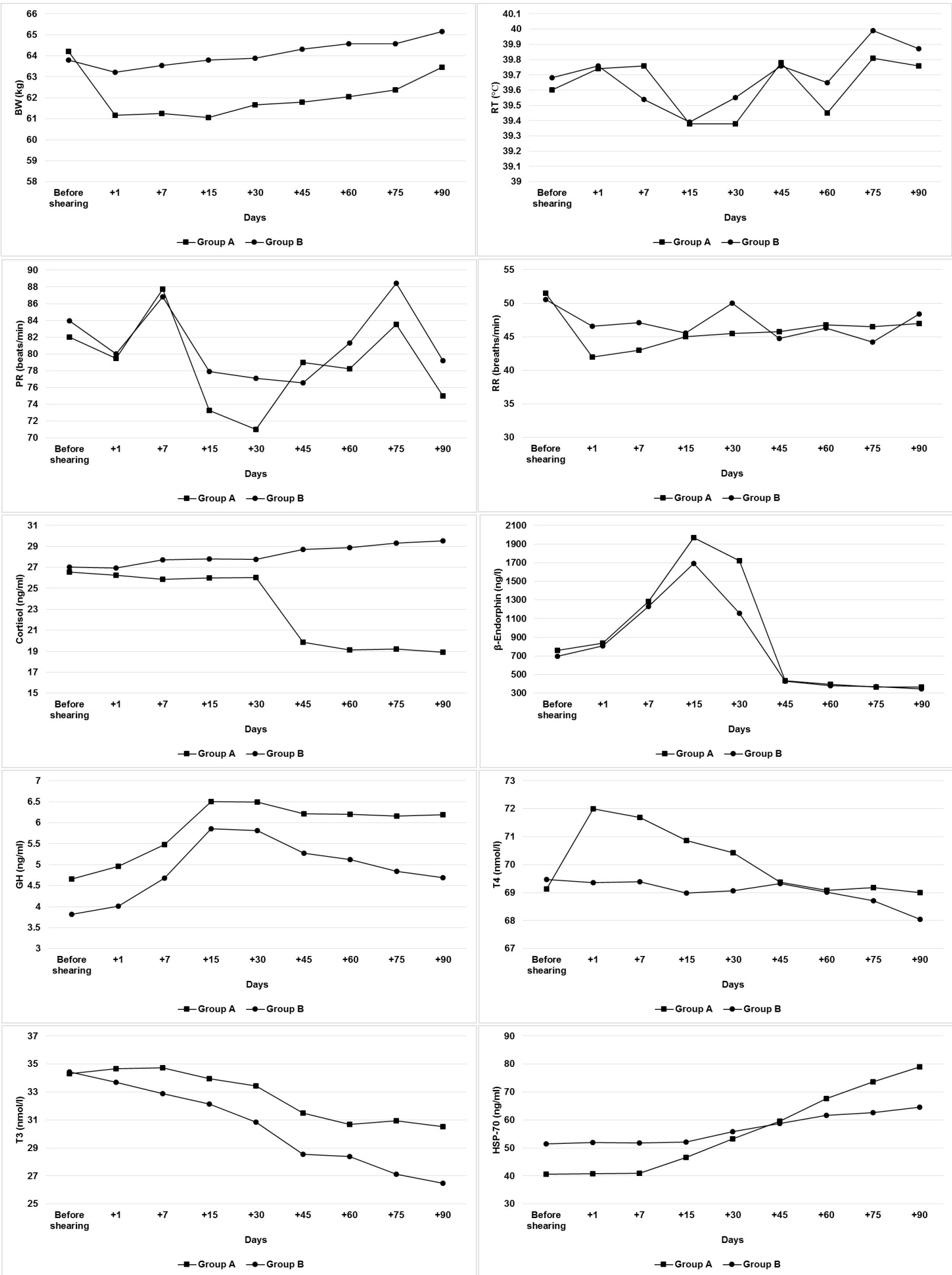

Figure 1. The patterns of BW, RT, PR, RR, cortisol, $\beta$-endorphin, $G H_{1} T_{4}, T_{3}$, and HSP-70 in both groups during the experiment. Group A, shorn group; Group B unshorn group; $B W$, body weight; $R T$, rectal temperature; $P R$, pulse rate; $R R$, respiratory rate; $G H$, growth hormone; $T_{4}$, thyroxine; $T_{3}$, triiodothyronine; HSP-70, heat shock protein 70 . Sampling was before shearing ( -1 day) and on days $+1,+7,+15,+30,+45,+60,+75$, and +90 following the shearing. 
ture. In this study $\mathrm{T}_{4}$ and $\mathrm{T}_{3}$ concentrations also decreased significantly due to increase of temperature. However, this decrease was higher in the unshorn group (group B). Besides, there was a significant increase in $\mathrm{T}_{4}$ and $\mathrm{T}_{3}$ concentrations in the shorn group immediately after the shearing (Figure 1). These increases in thyroid hormones may be caused by short-term stress. Acute physiological stress increases the secretion thyroid stimulating hormone from the pituitary gland and this increases the release of thyroid hormones from the thyroid gland to increase the metabolic rate [4].

The HSPs are a group of highly conserved proteins that are induced in both prokaryotes and eukaryotes by elevated temperatures or a variety of cellular stresses [38]. The HSP-70 has been most consistently associated with protection against conditions involving oxidative stress in organism [35]. In this study, while HSP-70 concentrations generally followed a flat trend up to the periods of heat stress, they showed a significant increase in periods of heat stress (Figure 1). It has been reported that HSP-70 is strictly stress-inducible and can only be detected following a significant stress upon the cell and organisms [39].

\section{IMPLICATIONS}

In this study, shearing caused short-term stress in shorn ewes but the ewes had rapidly regained their body homeostasis. In addition, the main effect of the shearing was observed during the periods of heat stress and shorn ewes were less affected from this stress. During the summer when sunlight comes at a right angle, shearing can be considered as a necessary management practice and the effect of heat stress can be reduced in sheep that are housed in shaded shelters.

\section{CONFLICT OF INTEREST}

We certify that there is no conflict of interest with any financial organization regarding the material discussed in the manuscript.

\section{ACKNOWLEDGMENTS}

The authors would like to thank manager and staff of Erciyes University Agricultural Research and Application Centre for their assistance.

\section{REFERENCES}

1. Carcangiu V, Vacca GM, Parmeggiani A, et al. The effect of shearing procedures on blood levels of growth hormone, cortisol and other stress haematochemical parameters in Sarda sheep. Animal 2008;2:606-12. https://doi.org/10.1017/S175 1731108001651
2. Dikmen S, Orman A, Ustuner H. The effect of shearing in a hot environment on some welfare indicators in Awassi lambs. Trop Anim Health Prod 2011;43:1327. https://doi.org/10.1007/ s11250-011-9859-4

3. Moberg GP. Biological response to stress: implications for animal welfare. In: Moberg GP, Mench JA, editors. The biology of animal stress: basic principles and implications for animal welfare. Guildford and King's Lynn, UK: CABI Publishing; 2000. p. 1-21. https://doi.org/10.1079/9780851993591.0001

4. Squires EJ. Applied animal endocrinology. Trowbridge, UK: CABI Publishing; 2003. https://doi.org/10.1079/978085199 5946.0000

5. Blokhuis HJ, Hopster H, Geverink NA, Korte SM, van Reenen CG. Studies of stress in farm animals. Comp Haematol Int 1998;8:94-101. https://doi.org/10.1007/BF02642498

6. Trevisi E, Bertoni G. Some physiological and biochemical methods for acute and chronic stress evaluation in dairy cows. Ital J Anim Sci 2009;8(Suppl 1):265-86. https://doi.org/10. 4081/ijas.2009.s1.265

7. Piccione G, Caola G, Refinetti R. Effect of shearing on the core body temperature of three breeds of Mediterranean sheep. Small Rumin Res 2002;46:211-5. https://doi.org/10.1016/ S0921-4488(02)00192-X

8. Piccione G, Casella S, Fazio F, Pennisi P. Effect of shearing on some haematochemical parameters in ewes. Czech J Anim Sci 2008;53:106-11. https://doi.org/10.17221/2713-CJAS

9. Dýrmundsson OR. Shearing time of sheep with special reference to conditions in northern Europe: a review. Bùvìsindi Icel Agric Sci 1991;5:39-46.

10. Piccione G, Casella S, Alberghina D, Zumbo A, Pennisi P. Impact of shearing on body weight and serum total proteins in ewes. Span J Agric Res 2010;8:342-6. https://doi.org/10. 5424/sjar/2010082-1217

11.Fidan AF, Kucukkurt I, Eryavuz A, Cigerci H, Yardimci M, Ozdemir A. Effects of shearing procedures on oxidant-antioxidant status in Chios sheep. Revue Méd Vét 2009;160:34955.

12.Sanger ME, Doyle RE, Hinch GN, Lee C. Sheep exhibit a positive judgement bias and stress-induced hyperthermia following shearing. Appl Anim Behav Sci 2011;131:94-103. https://doi.org/10.1016/j.applanim.2011.02.001

13. Yardimci M, Sahin EH, Cetingul IS, Bayram I, Aslan R, Sengor E. Stress responses to comparative handling procedures in sheep. Animal 2013;7:143-50. https://doi.org/10.1017/S17517 31112001449

14. Piccione G, Fazio F, Casella S, Pennisi P, Caola G. Influence of shearing on oxidative stress and some physiological parameters in ewes. Anim Sci J 2011;82:481-5. https://doi.org/10. 1111/j.1740-0929.2010.00865.x

15.Casella S, Giudice E, Passantino A, Zumbo A, Di Pietro S, Piccione G. Shearing induces secondary biomarkers responses of thermal stress in sheep. Anim Sci Pap Rep 2016;34:73-80. 
16. Pennisi P, Costa A, Biondi L, Avondo M, Piccione G. Influence of the fleece on thermal homeostasis and on body condition in Comisana ewe lambs. Anim Res 2004;53:13-9. https://doi. org/10.1051/animres:2003047

17. Aleksiev Y. The effect of shearing on the behaviour of some physiological responses in lactating Pleven blackhead ewes. Bulgarian J Agric Sci 2009;15:446-52.

18. Beatty DT, Barnes A, Fleming PA, Taylor E, Maloney SK. The effect of fleece on core and rumen temperature in sheep. J Therm Biol 2008;33:437-43. https://doi.org/10.1016/j.jtherbio. 2008.07.002

19. Climatic values: relational database [CD-ROM]. Ankara, Turkey: Turkish State Meteorological Service. 2016 Jun - 2016 Sep. CD-ROMs: 4 3\% in.

20. Marai IFM, Ayyat MS, Abd El-Monem UM. Growth performance and reproductive traits at first parity of New Zealand White female rabbits as affected by heat stress and its alleviation under Egyptian conditions. Trop Anim Health Prod 2001;33:451-62. https://doi.org/10.1023/A:1012772311177

21. Marai IFM, El-Darawany AA, Fadiel A, Abdel-Hafez MAM. Physiological traits as affected by heat stress in sheep-a review. Small Rumin Res 2007;71:1-12. https://doi.org/10.1016/j.small rumres.2006.10.003

22. Gürbüz F, Baspinar E, Camdeviren H, Keskin S. Analysis of the repeated measurement experiments. Van, Turkey: Yüzüncü Yll University Publications; 2003.

23. Hargreaves AL, Hutson GD. The stress response in sheep during routine handling procedures. Appl Anim Behav Sci 1990; 26:83-90. https://doi.org/10.1016/0168-1591(90)90089-V

24. Mears GJ, Brown FA. Cortisol and $\beta$-endorphin responses to physical and psychological stressors in lambs. Can J Anim Sci 1997;77:689-694. https://doi.org/10.4141/A97-051

25. Hefnawy A, Helal MAY, Sabek A, Shousha S. Clinical, behavioral and biochemical alterations due to shearing stress in Ossimi sheep. J Vet Med Sci 2018;80:1281-6. https://doi.org/ 10.1292/jvms.18-0150

26. West JW. Nutritional strategies for managing the heat-stressed dairy cow. J Anim Sci 1999;77 (Suppl 2):21-35. https://doi. org/10.2527/1997.77suppl_221x

27. Silanikove N. Effects of heat stress on the welfare of extensively managed domestic ruminants. Livest Prod Sci 2000;67:1-18. https://doi.org/10.1016/S0301-6226(00)00162-7

28. Wojtas K, Cwynar P, Kolacz R. Effect of thermal stress on physiological and blood parameters in Merino sheep. Bull Vet Inst Pulawy 2014;58:283-8. https://doi.org/10.2478/bvip2014-0043

29. Piccione G, Caola G. Influence of shearing on the circadian rhythm of body temperature in the sheep. J Vet Med A Physiol Pathol Clin Med 2003;50:235-40. https://doi.org/10.1046/j. 1439-0442.2003.00525.x

30.Piccione G, Lutri L, Casella S, Ferrantelli V, Pennisi P. Effect of shearing and environmental conditions on physiological mechanisms in ewes. J Environ Biol 2008;29:877-80.

31.Moslemipur F, Golzar-Adabi S. Physiological and growth parameters of fattening lambs after shearing under heat-stress conditions. Anim Prod Sci 2016;57:569-75. https://doi.org/ 10.1071/AN15001

32. Möstl E, Palme R. Hormones as indicators of stress. Domest Anim Endocrinol 2002;23:67-74. https://doi.org/10.1016/ S0739-7240(02)00146-7

33. Dobson H, Simith RF. What is stress, and how does it affect reproduction? Anim Reprod Sci 2000;60-61:743-52. https:// doi.org/10.1016/S0378-4320(00)00080-4

34. Yilmaz B. Hormones and reproductive physiology. Ankara, Turkey: Feryal Press; 1999.

35. Bernabucci U, Lacetera N, Baumgard LH, Rhoads RP, Ronchi B, Nardone A. Metabolic and hormonal acclimation to heat stress in domesticated ruminants. Animal 2010;4:1167-83. https://doi.org/10.1017/S175173111000090X

36. Trenkle A. Relation of hormonal variations to nutritional studies and metabolism of ruminants. J Dairy Sci 1978;61:281-93. https://doi.org/10.3168/jds.S0022-0302(78)83595-4

37. Todini L. Thyroid hormones in small ruminants: effects of endogenous, environmental and nutritional factors. Animal 2007;1:997-1008. https://doi.org/10.1017/S1751731107000262

38. Ross OA, Curran MD, Crum KA, Rea IM, Barnett YA, Middleton D. Increased frequency of the $2437 \mathrm{~T}$ allele of the heat shock protein 70-Hom gene in an aged Irish population. Exp Gerontol 2003;38:561-5. https://doi.org/10.1016/S0531-5565 (03)00006-8

39. Sejian V, Valtorta S, Gallardo M, Singh AK. Ameliorative measures to counteract environmental stresses. In: Sejian V, Naqvi S, Ezeji T, Lakritz J, Lal R, editors. Environmental stress and amelioration in livestock production. Berlin Heidelberg, Germany: Springer-Verlag; 2012. https://doi.org/ 10.1007/978-3642-29205-7 